\title{
Library and Librarians In Information Literacy for Life long Learning in University Education. B y Umar Babangida Dangani
}

\begin{abstract}
For one to be relevant in a world where the written word dominates does not only require good writing and reading skills but must also have the ability to think critically, read between the lines, use information socially and ethnically, share ideas and keep abreast with trend in IT. This paper traces the origin of the concept of information literacy its relevance to academic community and life long education. The roles of library and librarians in the design and inclusion of Information Literacy (IL) in to the curriculum of Nigerian Universities was also highlighted. The paper concludes that IL is a prerequisite for university graduate to successfully survive and compete in the $21^{\text {st }}$ century and beyond. The paper finally recommends Information Literacy blue prints for Nigeria universities.
\end{abstract}

\section{Introduction}

The $16^{\text {th }}$ century navigators were required to read the stars and understand tides to find their way, the same way today's scholars must learn to become information navigators, finding their way through print, graphic, electronic and visual media to discover and interpret relevant information. They must become critical thinkers and analyzers using technology to access, interpret and evaluate the quality and appropriateness of the information they have discovered.

Similarly, as navigators of old drew maps to share what they found with others, today's scholars must learn how to create and share knowledge using all the forms of telecommunications to communicate their ideas, engage in discourse, and solve problems, (Illinois State Board of Education, 1996:27). This statement eloquently details the need for academics to be technology literate. Familiarity with computers is becoming a prerequisite for most jobs. Educators must prepare students for the future by teaching them computer and information search skills, educators and the general public widely accept the premise that academics and students must be technologically competent to be successful today and in the future. However, competence with technology must be set within the context of information literacy. The US Department of labor Secretary's Commission on achieving necessary skills (SCANS) (1991) states that the competencies for all entry-level employees must include the ability to (1) acquire and use information and (2) work with a variety of technologies.

Information is certainly a vital element for creativity and innovation, a basic resource for learning and human thought, a key resources in creating more knowledgeable citizens, a factor that enables citizens to achieve better results in their academic lives, and important resource for national socio-economic development, Byerly and Brodie, 1999.

Information competencies are key factor in life long learning. They are the first step in achieving educational goals. The development of such competencies should take place throughout the citizens lives, especially during their educational years, where librarians as a part of the learning community and, as experts in information management have assumed a key role of facilitating information literacy. They contribute actively in their search and developed their skills, knowledge and values needed to become life long learners (Lau, 2006).

Adelaziz (2004) posits that information literacy is concerned with teaching and learning about the whole range of information sources and formats. To be information literate you need to know why, when and how to use all these tools and think critically about the information provided. It enables the graduates from Nigerian library schools to interpret and make informed judgments as users of information sources; it also enables them to become producers of information in their own right, thereby become more powerful participants in society. Information literacy is about developing people's critical and creative abilities.

Information literacy forms the basis for life long learning. It is common to all disciplines, to all learning environments and to all levels of education. It enables learners to master content and extend their investigations, become more self-.directed, and assumes greater control over their own learning.

\section{Concept of Information Literacy}

The concept of information literacy and skills has been interpreted in various ways since the early seventies. Terms such as study skills, research skills 
"Library skills, Bibliographic instruction, library orientation tend to be used in the educational context. Life long learning and creative thinking imply preparation for the work environment and continued productivity. The evolution of concept of information literacy, since Zurkowiski first used the term in 1974, has taken place both within and outside of the field of library and information science, not only in the United States but also throughout the world. Library educators have been especially sensitive to the so called information explosion and its resultants repercussions, Eisenberg, Lowe and Spitzer, 2005. Paul Zurkowiski, president of the Information industry association introduced the concept of information literacy, in a proposal submitted to the national communication on libraries and the National Commission on Library and Information Science (NCLIS). The proposal recommends that a national programme be established to achieve universal information literacy within the next decade. According to Zurkowiski, people trained in the application of information resources to their work can be called information literates. They have learned the techniques and skills for utilizing the wide range of information tools as well as primary sources in molding information - solutions to their problems, AASL, 1998.

Information literacy is a way of thinking and being that encompasses identifying, accessing, evaluating, organizing and communicating information. It is relevant in all learning environments and fields of endeavour. Individuals are faced with diverse information choices in their studies, in the work place, and in their lives. Sheer abundance of information and communication technology will no in itself create more informed citizens without a complementary understanding and capacity, to use information effectively; Australian and New Zealand information literacy framework, 2004:3.

Information literacy is derived from the Alexandria proclamation of 2005, adopted by UNESCO information for all programmes (IFAP), as essential for individuals to achieve personal, social, occupational and educational goals. IL skills are necessary for people to be effective life long learners and to contribute to knowledge socially, Catts and Jesus, 2008:7, 9.

In 1992, Doyle published the results of a Delphi study that expanded this definition. The participant in the Delphi study agreed on the attribute of an information literate person, proposing that such a person is one who, recognizes that accurate and complete information is the basis for intelligent decision-making; recognizes the need for information, formulates questions based on information needs, identifies potential sources of information; develops successful search strategies, accesses sources of information including computer based and other technologies, evaluates information; organizes information for practical application, integrates new information into an existing body of knowledge and uses information in critical thinking and problem solving, Doyle, 1992:8.

Since 1992, information literacy has been the topic of scores of publication and has been examined by educational institutions, professional organizations, and scholarly individuals, higher educational institutions have found campus wide committees to work toward including information literacy as a graduation outcome.

Information literate individuals are competent, independent learners. They know their information needs and actively engage in the world of ideas, they display confidence in their ability to solve problems and know what is revealed information. They operate comfortably in situation where there are multiple answers, as well as those with no answers. They hold high standard for their work and create quality products. Information literate academics are flexible, can adapt to change and are able to function independently and in groups, Colorado Educational Media Association 1994:1.

Inherent in the concept of IL is the ability to dissect and understand what we see on the page or the television screen, in posters, pictures and other images as well as what we hear. This will also involve ability to sort, discriminate, select and analyse the array of messages that are presented, Lenox and Walker, 199: 4 - 5.

Shapiro and Hughes (1996) commented that IL enables individuals not only to use information and information technology effectively and adopt to their constant changes but also to think critically about the entire information enterprise and information society. It is an intellectual framework for identifying, finding, understanding, evaluating and using information, it involves determining the nature and extent of needed information, accessing information effectively and efficiently, evaluating critically information and its sources, incorporating selected information in the learners knowledge base and value systems, using information effectively to accomplish specific purpose, understanding the economic, legal 
and social issues surrounding the use of information and information technology, and observing laws, regulations, and institutional policies related to the access and use of information...”

Information literacy requires an awareness of the way in which information system works and the dynamic between a particular information need and the sources and channels required to satisfy that need and this can only be achieved through the intervention of library and information science educators, Daren et al, 1997.

Seeker and Price (2004), also viewed information literacy as a term generally understood to include knowledge of information resources in one's subject, ability to construct effective search strategies, ability to critically appraise information sources and ability to use information sources appropriately cite and create references.

\section{Information Literacy and University Education} Information literacy is important to higher education, as it is a part of, and contributor to, lifelong learning. Inherent in the mission of university education institutions is the development of lifelong learners, who continue to learn beyond their formal education. If individuals are able to reason and think critically, and learn how to learn, they will be able to continue to grow intellectually throughout their careers, and contribute to society as informed citizens. Information literacy provides individuals with the tools to do so. Due to information literacy's importance in the higher education curriculum, certain regional and discipline-based accreditation associations now consider it as a significant outcome for university students in developed countries.

Information literacy education in the Nigerian library schools is necessary for both staff and students. The goal of information literacy education is to ensure that people are equipped and encouraged to learn from the range of information resources surrounding them. In other words they should acquire, over a course of study or through staff development opportunities, the characteristics of information literate people. Attention should be paid to the information literacy agenda when designing curriculum for library schools courses to ensures that information literacy is both the object of learning and the medium through which learning takes place.

Information literacy education involves learning to use the formal and informal networks available to individuals in their professional lives and as private citizens. Formal information networks are those available through libraries and information agencies. This involves, for example, access to scholarly and professional information, government information and information dissemination through the media. Informal information networks are those which provide access to information which has not yet entered the formal channels, or which does not properly belong to those channels.

The world is going digital now and this is influencing the way academics and students search for information. A particular challenge for today's educators and students in Nigerian tertiary institutions, understands the relationships between types of information resources, and how to evaluate the appropriateness and reliability of these resources and how to make intelligent choices among them.

The report of the National committee of enquiry into higher education (The Bearing report, 1998) had emphasized the importance of skills which are "key to the future success of graduates whatever they intend to do in later life and the report identified a list of four communication skills, numeracy, the use of information technology, and learning how to learn. The study of Ray and Day (1998) on students attitudes towards electronic resources, found that it is apparent that large numbers of students are leaving university without the necessary transferable skills to cope in an information based society.

The western association of schools and colleges in its handbook of accreditation standard (2001:20) notes that "there is the need to engage students in an integrated course of study of sufficient breadth and depth to prepare them for work, citizenship and a fulfilling life". These programs also ensure the development of core learning abilities and competencies including, but not limited to college level written and oral communications, college level quantitative skills, information literacy and the habit of critical analysis of data and argument.

Also, the New England association of schools and colleges (2001:19) now recognize information literacy as a student learning outcome in its accreditation standards. They recommend that professionally qualified and numerically adequate staff administers the institutions literacy, information resources and services. The institution includes appropriate orientation and training for use of these resources as well as instruction in basic information literacy. TheAmerican psychological association's board of educational affairs (2002:14) recognize information literacy as a specific learning objective for university graduate students (Murry, 2002) and 
notes in its learning goals, "students will demonstrate information competence and the ability to use computers and other technology for many purposes, including the demonstration of competent, ethical and responsible use of information.

American chemical society (2002) also states "a student who intends to become a practicing chemist, or who will use chemistry in allied fields of sciences and medicine, should know how to use chemical literature effectively and efficiently.”

\section{The Role of Library and Librarians in Information Literacy Programme}

Library and Librarians have played an integral part in the development of information literacy skills. The 1986Carnegie Foundation Report on Colleges outlined the importance of academic library programme to undergraduate experience: "The quality of a College is measured by the resources for learning in the campus and the extent to which the students become independent, self-directed learners", Prologue and Major Recommendations of Carnegie Foundation Reports on Colleges, 1986:21. Library educators lead the way in the early 1970s in conceptualizing the idea of information literacy and its relationship to life long learning. Early development of the concept of information literacy frequently focused on the future role of library and information science educators and librarians in helping the use and application of information, Beherens, 1994.

Gaffiths University, Australia (2008), in a blueprint states information literacy education is the shared responsibility of all educators and information providers. The document goes on to state 'effective information literacy education depends upon cooperation between information specialists and discipline experts to achieve curriculum innovations, which foster information literacy. Hartxel (2002) notes that quality library programes can positively affect academic productivity. Similarly, Caspera, (2001:130) observed that, library and Librarians are essential to academics and students, and most researches are in agreement that librarians support is a key element in information literacy skills. This implies that the Library and librarians are involved in a number of ways in the process of impacting the information literacy skills to students and this can be done in terms of teaching and providing relevant materials, facilitating the use of those materials and ensure that they are made aware of their critical role and importance to their learning.
The development of information literacy is reported to be especially successful when library develops partnerships with faculty members and as partners, incorporate information literacy programmes into the academic curriculum, Amstutz and Whitson, 1997. Emerging critical role for librarians include working with other academics to ensure appropriate inclusion of information seeking in courses offered in flexible delivery mode, seeking out memberships in course development teams, Austen, 1998. It is clear that library school students cannot learn information literacy on their own without a concerted instructional effort that gives multiple opportunities to practice their information literacy skills. The librarians are also in a better position to assist academic community have multiple experiences to practice information literacy skills before graduating. They play an important role in the education process by making students aware of a need and motivating the use of information, a new knowledge and a new ability,”. Brooking Negraw et al 1990:35.

Brevik (1996) states that librarians must operate in the broader educational and information policy environment, help shape those environment and build partnership in society in order to promote desired outcome. According to Sullivan and Campbell (1991:184) the bridges needed to overcome existing gaps between librarians and the society's information needs require essentially two things; librarians need to educate and re-educate themselves acquire knowledge, skills and competence for a new role, and also need to cultivate the concept of life-long learning through information literacy skills acquired and developed both in the school and out of school. They must encourage students to question their findings every step of the way in the research process, especially as new format are made available.

\section{Information Literacy and Life Long Learning}

Information literacy and lifelong learning have a strategic, mutually reinforcing relationship with each other that is critical to the success of every individual, organization, institution, and nation-state in the global information society.

Information literacy which was developed from library instruction has been the term most frequently used since the late nineteenth, information literary is considered a survival skill for the new century, the key competency for independent study self-directed learning, life long learning, and the foundation for a literate society. Information literacy is important to student of library schools and considered a desirable outcome of higher education, Lance and Potter, 
1995:126. Information literacy competences are desirable for all graduates.

The complex world in which we live now contains a lot of information resources in various formats which include print, electronic, image, spatial, sound, visual and numeric. The problem now is not having enough information but rather too much information in different format that not all are of value. Roth (1990:42) aptly describes the current information environment and the pitfalls facing library, with the explosion of information generated and stored, culture, the development of sound and video archives, and the case of seemingly infinite reproduction of words and pictures through unregulated sprawl of the internet, the shift from a print to an image based electronic media, the pitfalls for library schools have multiplied geometrically. There is so much information through so many different platforms. In this new climate, the public interest changed beyond access and equity but sorting and selection. The challenge of education is to help students make sense of a world described by some as information overload.

It was also noted by the Boyer commission on educating undergraduates (1998) that undergraduate education should be designed as a continuum that prepares student for continual learning and professional work through developing their talents to information questions and seek answers. Information literacy is a key component for doing so. It is obvious that there is a lot of information resulting to information overload and in different formats and the only way scholars and students can find and access the relevant information is when the educational system especially the university help develop their talents and skill that will help them find, access and evaluate the needed information effectively and efficiently.

\section{Conclusion}

Information literacy is a pre-requisite for people and institutions to successfully survive and compete in the $21^{\text {st }}$ century and beyond. It can be concluded that for one to be relevant in a world where the written word dominates does not only require good writing and reading skills but also have the ability to think critically, to read between lines, share ideas and build collective action that will ensure mastery of IL skills in Nigerian library schools. This will certainly have positive impact on teaching, learning and scholarship.
Since information literacy is not just a library issue, it now of keen importance to all educational stakeholders, including administrators, librarians, media and information technology specialist, career development professionals, there is the need for them to make collaborative effort to enhance IL in Nigeria library schools.

1. Information literacy should be incorporated into the curriculum of Nigerian library schools. It should be also be made one of the desired learning outcome required for graduation.

2. Library should also encourage students to acquire IL skills in their process of teaching and learning so as to complement the effort of the librarians.

3. State of the Art ICT facilities should be provided to library for IL practice.

4. Librarians and other stakeholders need to be retrained on the latest trend in IL practice.

\section{References}

Adalian, P. et al (1997) The Student - centered Electronic teaching: A new model for learning. Reference service Review, 25 (fall/winter), 1121,

Amstutz, D. and Winston, D. (1997) University Faculty and Information literacy: Who teaches the student? Research strategies 15, winter, 1825.

American Library Association (1989), Presidential Committee on Information literacy. "Final Report”. Retrieved on 3/3/2009 from http://www.ala.org/content/navigation menu/ACRL/publication/white papers-and Reports/presidential-committee-on-informationliteracy.htm.

American Chemical Society (2002), "Chemical information Retrieval.” Retrieved on 2/3/2008 from http://www.chemistry.org/portal/chemistry? PID=acs display.htm/\$ DOC=education\%5Ccpt\%5cts-cheminfo.html.

American Psychological Association, Board of Educational Affairs (2000( "Undergraduate Psychology Major learning Goals and outcomes: a report."Retrieved on 8/9/2008 from http://www.apa org/puce/taskforce report.pdf.

Association of College and Research Libraries (2000), Information Literacy Competency standards for Higher Education Chicago: Association of College and Research Libraries. Also available at http://www. Ala.org/content/navigation menu/ACRL/standards-and-

\section{Recommendation}


Guidelines/information-literacy-conpetencystandards-for-higher-education.htm

Baron, Leora (2001), "Why Information Literacy: Empowering Teachers and Students in the Classroom and Beyond,” NEA Higher Education advocate Outline Aug. Retrieved on 2/4/2009 from http://www.nea.org/he/advo OI/advoOI08 front.html

Boyer, Ernest L. "New Technologies and the public interest in Education speeches 1979-1995. Princeton;' N.J.: Carnegie for the advancement of teaching

Boyer Commission (2001:12) Educating Undergraduate in the Research University "Reinventing Undergraduate Education: Three years after the Boyer Report.". Retrieved on 1/2/2009 from http://www.Sumysh.edu/pres /0210060Boyer\%20Report\%20final.pdf.

Bruce, C.S (2002) Information literacy as a catalyst for educational change: a background paper: white paper prepared for UNESCO, the US National Commission on Libraries and Information Science, and the National Forum on Information Literacy, for use at the information literacy meeting of experts. Orague, the Czech Republic Available. At htt://www.nelis.gov/hbmter infolitconf and meet/papers/bruce-full paper: pdf accessed on 6/7/2005.as in international forum of Research in education vol. 2. No. 1 and 2, 2005

Breen, E. and Fallon, H. (2005) developing student information literacy to support project and problem base learning in T. Barrett, I. Mac Laburainn, it. Fa (eds). Hand book of enquired and problem based.

Brooking, Negroa et al (1990) Public Libraries Information and citizenship, $56^{\text {th }}$ IFLA General Conference, Sweden 18-24 August 1990. Booklet 8. p. 35.

Brevick, P.S. (1991) A signal for the need to restructure the learning process, NASSP Bulletin 75 (535), 1-7.

Brevick, Patricean S. (1996) "Working Together for a Better Tomorrow" Guest Editorial College and Research Libraries, 57 (2) 110-112.

Casper, J.(2006), Beyond the rhetoric: a study of the Impact of the ACRL guidelines for distance learning library service on selected distance learning library service on selected distance learning programs in higher education journal of library Association 31 (3/4) p. 130.

Eisenbery, M.B., Lowe, C.A. and Spitzer, K.L. (2004) Information Literacy: essential skills for the Information age Westport, Connecticut: Libraries unlimited.
Faust, Judith. (2001) "Teaching Information Literacy in 50 minutes a week: the CSULT experience.” Journal of southern Academic and spread Librarianship, 21(3)

Gassol, de itorowtz Rosqril (1998) Librarianship: A third world perspective.

Griffiths University, Division of Information Service, (1994) Information Literary Blueprint,

Hartzeu, Laura A. (2002) "Capitalizing on the school library's potential to positively affect student Achievement" Retrieved on 4/4/2009 from http://www.imis.gov/pules/whitehouse. 0602/ Resources.pdf.

Hinchiffe, L.J. and Woodard, B.s (2001) Instruction in: R.H Bopp and L.C. Smith (ed.) Reference and Information Services: an Introduction Eaglewood, Colorado: Libraries Unlimited, Inc., p. 177-209.

Jones, Steve (2002). "The internet goes to college how students are wing in the future with today's technology.” Sept. 15,. Pew and American life Project. Retrieved on 1/2/2009 from http://www/pewinternet.org/reports/pdfs/pipcollege-report-pdf.

Middle states commission on Higher Education (2001), execution summary. Developing Research and communication Guidelines for Information literacy in the Curriculum "professional standards for the Accreditation of school, college and Department of education" Retrieved on 3/4/2009 from http://www.ncate.org/standard/m-stds.ntm.

New England Association of schools and college, Commission on institution of Higher (2001:19). "Standard 7: Library and Information Resources, Standard for Accreditation". Retrieved on 3/4/2009 from http://www.neasc.org /cihe/standards.pdf.

Ojedokun, Ajoku A. (2007) Information literacy for Tertiary Education Students in Africa, Ibadan: third world Information service United.

Roth, Lone "Educating the cut and paste Generation." Library journal, Nov. 1, 1999, 124 (18), $42-44$.

Ray, Kalhryn and Joan Day. (1998) "Student Attitudes toward Electronic Resources." Information Research, Oct., 4 (2)

Rader, H. (2003) Information Literacy-a Global perspective in A. Martin and $\mathrm{H}$. Rader (Eds) information and IT Literacy: enabling learning in the $21^{\text {st }}$ century. London, Facet publishing p. 2442.

Stanford, Stephanie. (2000) "Terry Crane: In spring Connections.” Coverage, Sept,.http://www.coveragemeg.com/publication/ CNVG Sept 00 profilecrane/profile.sntml. 
Sullivan, Laura A., and Naney, Campbell F. (1991) Strengthening the Foundation for information literacy in an Academic Library. The reference Librarian (U.S.A) No.33: 183-189.

Shapiro, J.J and Hughes. S.K (1996) Information Literacy as a Liberal art enlightenment proposals for a new curriculum, Educom Review. 31 (2), 31-35 http://www.educause.edu.
Western Association of Schools and Colleges (2001), "Standard 2." In handbook of Accreditation. Retrieved on 4/2/2009 from http://www.wascweb.org/senior/handbook.pdf

Work Group on Information Competence (1995:9) "Information Competence in California State University: A report. Retrieved on 1/4/2009 from http://www.calstate edu/ls/About info comp.sntml. 